\title{
The Role of Religion in the Life of Zainichi Koreans in Japan
}

\author{
Nataša VISOČNIK*
}

\begin{abstract}
Among the many elements that define people's identity is ethnicity, which refers mainly to a person's or a group's sociocultural heritage, based on characteristics such as common or shared national origin, language, religion, dietary preferences, dress and manners, and other traits that denote a common ancestry. Religious identity, especially if shared, can influence one's socioeconomic adjustment within an ethnic boundary that promotes ethnic identity, and religious faith can be a source of ethnic and even inter-ethnic solidarity. Korean immigrants in Japan established numerous mutual aid organizations, religious institutions, and self-governing bodies that aimed to promote the welfare of Korean communities, and thus work to establish the Korean identity in Japan. The religious practice of Japan's Korean minority represents Confucianism, Christianity, shamanism, and Buddhism, or even a combination of two or more of them. This paper asks whether religion worked as a strong homogenising and distinguishing factor in the case of Korean minority and how did this role change through the generations of Koreans in Japan?
\end{abstract}

Keywords: Zainichi Koreans, religions, folk religion, identity, representations

\section{Izvleček}

Med elementi, ki definirajo človekovo identiteto, je tudi etničnost. Ta se nanaša na osebno ali skupinsko kulturno dediščino, ki temelji na značilnostih, kot so skupen izvor, jezik, religija, prehrana, oblačila, navade ter drugi elementi, izhajajoči iz skupnih prednikov. Religiozna identiteta, predvsem skupinska, lahko vpliva na družbenoekonomsko prilagajanje posameznika znotraj etničnih meja, ki vplivajo na etnično identiteto. Religiozno verovanje je lahko tudi vir etnične ter medetnične solidarnosti. Korejski migranti na Japonskem so ustanovili številne organizacije medsebojne pomoči, religijske institucije in samoupravne organe. Njihov cilj je doseči blaginjo korejske skupnosti, zaradi česar se trudijo na Japonskem vzpostaviti korejsko identiteto. Religijsko udejstvovanje korejske manjšine predstavljajo različna verovanja, kot so konfucianizem, krščanstvo, šamanizem, budizem, ali pa kombinacija več verovanj, npr. šamanizma in budizma. Glavno vprašanje predstavitve je, ali je religija za Korejce res faktor poenotenja in razločevanja od drugih in kako se ta vloga spreminja skozi generacije Korejcev na Japonskem.

Ključne besede: Korejci Zainichi, religije, ljudske religije, identiteta, predstavitve

Nataša VISOČNIk, Assistant Professor at Department of Asian Studies, Faculty of Arts, University of Ljubljana. natasa.visocnik[at]guest.arnes.si

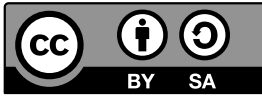




\section{Outline}

As many other minority groups living in a diaspora, the Korean minority in Japan challenges the assumption that the national state is "homogeneous", a notion that has prevailed in Japan for many years. The case of Koreans in Japan is, however, a very complicated one and is thus a topic that many studies have been investigating from various points of view. Chapman $(2006,90)$ emphasizes that, since Japan has lived under an ideology of homogenised national identity, the existence of resident Koreans has been seen as a "problem" in Japanese society from most of the post-war period. The diaspora has historically struggled against legislative and social exclusion and attempts at assimilation. But these struggles have caused social change, and recognition of an ethnically diverse population, such as in recent years the notion of a "multicultural Japan", has has been gaining in recognition.

This recent research ${ }^{1}$ has focused on the study of diversity, mutual representations, and the expression of identity of Korean minority group in Japan, which advances through the assertion of their existence and value in a foreign country, through the analysis of the problems of their non-acknowledgment, and through giving them a voice. The question of identity in general and national and ethnic identity in particular requires not just a subject's identification with a specific space as home, but also the examination of the process of production and reproduction of such an identity. The paper focuses on the problems that the minority group of resident Koreans have with understanding, expressing, and representing their identities, while rising questions as to what it means to be "Korean" in Japan.

As the processes of identity formation always occur inside socio-political and cultural contexts, the members of minority communities are often confronted with a multitude of "others", towards whom quite different designs of identity may be presented. Among the many elements that define people's identity is ethnicity, which refers mainly to a person's or a group's sociocultural heritage, based on such characteristics as common or shared national origin, language, religion, dietary preferences, dress and manners, as well as other traits that denote a common ancestry (Kokot et al.2004, 7). Regarding the religious faith Oleg Pakhomov (2011, 5) points out that it can even be a source of ethnic and even inter-ethnic solidarity. Religious identities, especially if shared, can influence socioeconomic adjustment within an ethnic boundary that "promotes ethnic identity and endogamy" (ibid.). Religious motivation can reproduce ethnic differences in different ways or reduce

1 The research is based on the fieldwork conducted mostly in Kyoto, but some interviews were also done in Ōsaka in 2012 and 2014. The fieldwork in 2012 was financially supported by Japan Foundation and supervised by Professor Ogura Kizo from Kyoto University. 
individual anxiety and disappointments from contingent cultural or intergenerational differences.

This paper, however, deals with the role of religion in the process by which the Zainichi Koreans in Japan formed their identity. Korean immigrants in Japan established numerous mutual aid organizations, religious institutions, and self-governing bodies that aimed to promote the welfare of Korean communities, and thus work to establish the Korean identity in Japan (Hardacre 1986, 31). The minority has developed unique practices in Japan, but the questions this paper poses include whether this religion worked as a strong homogenising factor among Zainichi Koreans and a factor that distinguished them from the Japanese, like it may has worked for some other ethnic group around the world, and how this role is changing through the generations of Koreans in Japan.

\section{Koreans in Japan}

Koreans constitute the largest "foreign"2 community permanently residing in Japan. Slightly more than 40 percent of all registered foreigners in Japan are Koreans. This number includes both Zainichi Koreans and recent newcomers from South Korea. Despite their similarities in physical appearance and considerable acculturation to mainstream Japanese society, Koreans in Japan have been discriminated against by both the Japanese state and Japanese society. Zainichi Koreans, those who came to Japan during Japan's occupational period over Korea and their descendants, are classified into two groups: North Koreans and South Koreans. Zainichi Koreans are also customarily distinguished from newcomers by either Japanese society or the Japanese state (Kokot et al. 2004, 7; see also Chapman 2006; Ryang 2005).

They mostly carry Korean citizenship, as Japan is a jus sanguinis (law of the blood) rather than a jus soli (law of the sun) state, which means one must have at least one parent of Japanese nationality to claim citizenship. It is possible to naturalize, but although naturalization requirements are eased for Zainichi Koreans, it can still be a complex, bureaucratic process, in which one must usually change Korean names into Japanese ones. In addition, because Japan does not recognize dual citizenship, a prospective naturalized citizen must also renounce their Korean citizenship (see

2 According to statistics from the Ministry of Justice, there were 497,707 Koreans in Japan in 2015. This figure does not include those who have adopted Japanese citizenship, which might be around 268,399 according to the figures from 2005. Added to this number should also be long-term visitors $(66,291)$, and Korean students in Japan $(15,718)$ who make up 848,115 in total (Ministry of Justice 2015). 
Brown 2015). In Japan, Zainichi Koreans have a "Special Permanent Resident" status under which they enjoy access to the Japanese social welfare, pension, and health insurance systems. However, they do not have the right to vote, and there are some pension and social welfare clauses which do not apply to them.

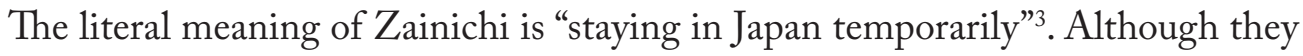
have been living in Japan since the Japanese Occupation of Korea in 1910 or later, they are still called "temporary" residents. This term reflects the desire of many Koreans to someday return to their mother country — especially after World War II, when the Allied Powers defeated Japan, liberated Koreans in Japan had a strong desire to go back to Korea. However, those ambitions faded over time. Zainichi Koreans, now in their fourth generation, are permanent residents of Japan, and many of them no longer have a desire to go back. Despite this, the term has survived, reflecting the reality of institutional discrimination by the Japanese state and Japanese society (Kokot et al. 2004, 7; see more in Visočnik 2003).

As mentioned, there are two main political separations, regarding their affiliation with either South or North Korea, and thus two ${ }^{4}$ political advocacy organizations with which Zainichi Koreans become involved: Mindan ${ }^{5}$ and Chongryon ${ }^{6}$. Mindan, established in 1946, is generally considered to be pro-South Korea, while Chongryon, established in 1955, maintains ties to North Korea (Ryang 2005) and claims to follow the North Korean juche ideology ${ }^{7}$. About 65 percent of Zainichi

3 The term Zainichi (在日) emphasizes place of residence rather than bloodline. Since the late 1970s, the younger generation has used the term to emphasize their different approach to living in Japan to that of the first generation Zainichi. This term also avoids the inclusion of nationality as a defining element in identifying this community (Chapman 2008, 4-5; Inadsugi 2002, 559-62).

4 There is also a third group that is more oriented towards the practical needs of the community called Mintōren (民闘連), which is not divided between the two Koreas. It is not a formalized organization but holds annual conferences and mobilizes support and contributions wherever and whenever issues present themselves (Hicks 1998,22).

5 An abbreviation of the Japanese name Zai-Nippon Daikan Minkoku Kyoryūmindan (在日本大韓 民国居留民団).

6 In Japanese it is called Soren (総聯), an abbreviation of Zai-Nippon Chosenjin Sorengokai (在日 本朝鮮人総聯合会) (Hicks 1998, 22), which translates as General Association of Korean Residents in Japan.

7 The political philosophy known as juche became the official autarkic state ideology of the Democratic People's Republic of Korea (DPRK) in 1972. Although foreign scholars often describe juche as "self-reliance", the true meaning of the term is much more nuanced. Kim Il Sung explained that it means to be the "master of revolution and reconstruction in one's own country. This means holding fast to an independent position, rejecting dependence on others, using one's own brains, believing in one's own strength, displaying the revolutionary spirit of self-reliance, and thus solving one's own problems for oneself on one's own responsibility under all circumstances" (Lee 2003). The idea of Juche, also known "Kimilsungism" after Kim Ilsung, is the religious, political, social and economic ideology of North Korea (North Korean Christianity; see also Clark 2000, 56-9). 
Koreans are affiliated with Mindan, while 25 percent are associated with Chongryon. In general, Chongryon has been the more pointedly nationalistic of the two organizations, encouraging Zainichi Koreans to maintain their Korean identities and eschew assimilation into Japanese society. Mindan, on the other hand, has been quite active in the movement supporting suffrage for Zainichi Koreans, but both organizations promote Korean culture and advocate for economic opportunities for Zainichi Koreans (Brown 2015, 256).

Beside the conflicting allegiance to the two Koreas, for most Zainichi their sense of self is characterized by numerous conflicting and contesting notions of identity. These are chiefly discussed in diametrical opposing opinions (Chapman 2008, 5); the different sense of one's place and time in Japan (temporary versus permanent), intergenerational tensions and discrimination by Japanese state-controlled institutions that have spanned decades. These all indicate the great complexity of life for many of the Zainichi population living in Japan.

The younger generations do not necessarily feel that the Korean peninsula is their homeland any longer; that their permanent residence in Japan has become an undeniable fact. Since the early 1980s they have displayed more affirmative views of their own hybridity, and a search for a third way "looking neither toward naturalization, which would require them to abandon their ethnicity, nor toward returning to a divided or even unified homeland" (Iwabuchi 2005, 68).

Here we will discuss the religious affiliation of the group that is pro-South Korea, although a certain number of pro-North Korean people practice one or a combination of religions.

\section{The Role of the Religion in Identity Formation of Minority Groups}

Any research into identity and diaspora must therefore take into account a great variety and heterogeneity of identities at any given point in time, among which "diaspora ${ }^{8}$ identity" is only one, although a formative, part. Kokot et al. (2004, 6-7) continue that, in the context of diaspora, religion has always remained central to paradigmatic definitions. A focus on both sides of diasporic practice is bringing the meaning of religion to the fore, discussing the meaning of religion

8 In past decades, the meaning of the term "diaspora" has been extended from long-established diasporas like the Jewish, Armenian, or Greek experience, towards a host of new and more contested areas of reference.

9 The "essences" of identity are seen by many anthropologists merely as the content of an ongoing process of boundary construction, being constantly re-invented and shifted according to the requirements of the situation (Kokot et al. 2004, 4). 
both as a factor in forming diasporic social organization, as well as in shaping and maintaining diasporic identities. As these studies point out, an interest in religious identification and practice can be observed in various social and cultural contexts, challenging the emphasis on the vanishing of religion in modernists' discourses.

Dru C. Gladney $(2008,8)$ argues out that "religion may define majorityness as often as other naturalized categories such as culture, race, ethnicity, locality, and language". He points out that, according to Keyes, Kendall, and Hardacre religion, such as state Shintoism in Japan and Islam in Southeast Asia, plays an important role in defining who is included in or excluded from certain configurations of power and authority. Religion may be the main factor determining one's political or national affiliation (Hindu/Muslim in India, Protestant/Catholic in Ireland, and Malay Muslim/Chinese in Malaysia, respectively) (ibid.).

With a provisional definition of religion it can be said that "it is a system of belief capable of organizing the life-words of entire social groups" (Pace 2005, 133), which also means that it gives meaning to social and individual action with adhering to norms, it can also create places where social ties, networks and representation are facilitated, and it can establish a principle of authority and power. When a religion can function as a belief system, it may become a medium of communication (ibid.) and also a source of ethnic and even inter-ethnic solidarity (Kokot et al. 2004,7). This means that it is capable of reducing the complexity of the social environment and thus creates religious identity, and, especially if shared, can influence one's socioeconomic adjustment within an ethnic boundary that "promotes ethnic identity and endogamy" (Pakhomov 2011, 5). In the process of social de-contextualization, which means that the new environment is much more complex and diffentiated than the previous one (Pace 2005, 114), religious motivation can besides creating ethnic differences, reduce individual anxiety and disappointments from contingent cultural or intergenerational differences (Kokot et al. 2004, 7).

Being in a diaspora environment can cause a tension between an original religious belief that immigrants bring with them and the new social environment. These tensions can be solved in different ways as Enzo Pace shows: the diaspora model (maintain group's own specificity), politicization of belief (re-create the community lifestyle and transform the group cohesion), compromise model (yield some influence from the hosting society), and individualization of belief (process of secularization, individual choice) (Pace 2005, 115). These factors depend on the crossing of adhesion to the principle of authority on which a religious system is based and the amount of freedom of religious expression in a new country on one hand, and the adaptation process to the new social environment on the other. 
While these processes can be easily detected if the migrant group has a single religious belief, in the case of Zainichi Koreans we can find not just one, but at least two of them, as will be shown later.

\section{The Religions of Zainichi Koreans in Japan}

There are many world religions and native beliefs in Korea, but there is no severe conflict among them. ${ }^{10}$ Some of them are established religions such as Buddhism (25\%), Confucianism (2\%), and Christianity (25\%); newly rising religions include the Unification Church and several other denominations that have derived from Christianity, varieties of Buddhism, and the Korean Religion of the Heavenly Way (Ch'ondokyo), and there are also popular religions like shamanism. The same can be said for the religious activity of the Korean residents of Japan, who combine several revivals of traditional beliefs (with some unique changes) and an assimilation of Japanese religions. In Zainichi Korean society we can find Shamanism, Confucianism, Korean Buddhism, Zainichi Christian Church Associations, and also various Japanese religions including folk religion, Buddhism, Shintoism, and new religions (Iida 2002, 35).

Iida Takafumi $(2002,58)$ continues that the religion in Japan-resident Korean society is a complex fusion of interrelated facets. Furthermore, among the Japan-resident Koreans there is a considerable difference between the religious faith and practice of the "oldcomers" (the Koreans who came to Japan before World War II and their succeeding generations) and that of the "newcomers" (those who came to Japan from the 1970s and after). If we categorize these groupings into ethnic-culturally oriented (that is, "assimilation" oriented, Zainichi oriented, homeland oriented) and organizational/network (voluntary networking, formal organization network) types, we may lay out the various categories (ibid., 58).

These networks are very important for Korean people because as they provide connections with their origins, their homeland, other Korean people living in Japan or elsewhere, with the neighbourhood and local Zainichi Korean and

10 However, while many Koreans feel compelled to pick one or another label when they are surveyed, in fact many do not belong to any single tradition but think of themselves as belonging to several at once, being comfortable with a mix of symbols and rituals (Clark 2000, 29, 30).

In North Korea today, as mentioned, the state officially discourages the practice of religion, regarding it unscientific, superstitious, and a vestige of the feudal past. A certain number of people continue to practice Buddhism, Protestant and Catholic Christianity, and Ch'ondokyo, but they have to belong to state-sponsored religious organizations that are closely monitored by the government (ibid., 29). 
Japanese communities, all contributing toward broadening the circle of one's friends. These communities give them a goal and orientation in everyday life by offering them several activities, economic mobility, organized festivals, Korean centers, help with legal, economic, and political matters, and so on. Regarding the religion these networks include shamanistic and Confucianistic rituals, rituals of folk religion, Buddhism, death memorial services, and so on, for example: Ikoma Mountain Hozanji temple Organization (生駒宝山寺講), Zainichi Kwang San Kim Shi Shinzokukai (在日光山金氏親族会 ${ }^{11}$ ), Shinnyo-en (真如 苑, Borderless Garden of Truth) $)^{12}$, Kakyō Fudoshōekai (華僑 普度勝会 ${ }^{13}$ ) (Iida 2002, 33-4).

\section{Christianity}

Christianity has a very turbulent history in Korea too, going from the suffering and sacrifice of Korean Christians, to being widespread in the period of modern Korea, which made Christianity a refuge and force for reform (Clark 2000, 52). In Japan however, there is no widespread growth like that on the Korean mainland. The main Protestant organization is the Zainichi Daikan Kirisuto Kyokai Sokai 在日大韓基督教会総会 (Korean Christian Church in Japan) with 58 churches, claiming 4,803 members throughout Japan. Eleven of these churches, with 1,460 members, are located in Ōsaka (Iida 1988,158) and a few can also be found in Kyōto.

The total number of Christians among Korean residents comes to less than 1\%, even when taking into consideration the members of Catholic and other Protestant churches. This percentage is about the same as for Christians in Japan as a whole. On the other hand, the Korean Christian churches are actively involved in solving the topics of discrimination and human rights among Korean residents in Japan, and have an important impact on Korean residents and Japanese society (ibid., 159).

11 According to Ogawa and Teraoka (1993) in their article the networks, whose basis are the sameness of kinship, shared attachment to hometowns and nearby residents. One such network is the Korean Kinship Organization in Japan.

12 In Kyōto there are two temples: Shinnyoen Kyōto Temple and Kyōto Training Center. Shinnyo-en temples and centers are sacred space created to support practitioners' training. One way to look at a Buddhist temple, and Buddhism itself, is as a refuge where a practitioner can recharge their spiritual batteries. The temple and all that transpires there allows practitioners to reconnect with the expansive goodness of their Buddha nature. As such, the temple is considered a "sacred" space.

13 This is an organization for overseas Chinese, which offers the service to other minorities as well. The Chinese are the second-largest minority group in Japan. 
Within The Korean Christian Church in Japan there are two distinct groups, each with their own leanings. One is a group that gives specific weight to taking on the aforementioned social issues, which we might call the "Society-Oriented Group", and the other group, which we might call the "Gospel-Oriented Group", puts emphasis on salvation from within (Iida 2002, 297). Perhaps some several thousand Japan-resident Korean Christians belong to the Catholic Church, but the actual figure is unclear. Ethnic aspects of this community are not particularly emphasized, and most members use Japanese names (tsümei 通 名) (Iida 2013, 128).

\section{Buddhism}

Since its arrival in Korea (BCE 372) Buddhism has flourished and has had great influence on Korean culture. During its existence in Korea it has also absorbed and adjusted to other religions or civil thought, such as Confucian social norms (Clark 2000, 40). When Japanese culture began to influence Korea, Korean Buddhism split into the Choge order, which remained celibate, and the Taego order, which allowed monks to marry. Later this dispute was settled, both sects now allow monks to marry, but some differences and the division remained (ibid., 42-3).

As for Buddhism, there are seven temples in Japan (two in Ōsaka, four in Tōkyō, one in Kyōto) with 7,950 members (4,300 in Ōsaka, 2,150 in Tōkyō, and 1,500 in Kyōto) belonging to the Choge sect, the main Buddhist organization in Korea. Their headquarters are located at Fugen-ji 普賢寺 in the Ikuno district of Ōsaka. This temple was built in 1968. However, it appears that the establishment of orthodox Buddhism lags behind the spontaneous acceptance of shamanistic beliefs or the proclamation of Christianity among resident Koreans. Temples of the Choge sect are in urban areas and rather inconspicuous, with the exception of the one in Kyōto, which is built in Korean style, deep in the mountains, and has begun to manage a large cemetery. Other Korean sects include the Taego sect, which has a number of temples. The headquarters in Seoul does not recognize them as branch temples; they could rather be considered as particular examples of syncretistic folk religions (Iida 1988, 159).

\section{Confucianism}

Confucianism still provides the fundamental moral structure for the daily life of resident Koreans, it is a value system that seeks to bring harmony to the lives of 
people in communities - the family, the village, and the state. It plays an important role in providing ceremonies for funeral and ancestor rites, such as chesa $a^{14}$ (Clark 2000,31-33). Respect for elders, the dominance of the male over female, ancestor worship, and kinship consciousness are all stronger among Korean residents than among the Japanese. Funeral rites in particular are still maintained in the traditional Confucian way, and serve as a reminder of their ethnic identity to younger Koreans, who are more conscious of being "Japanized". However, Confucianism as a religion neither has an organized institution nor an educational system, and it appears that its moral influence is waning among the increasing number of Japan-born Korean residents (Iida 1988, 158).

\section{Shamanism}

At the dawn of the modern age in Korea, shamanism accounted for the whole rich tradition of Korean spiritual belief. Though the rich variety of folk deities still is part of Korean conversation and consciousness, "shamanism" as such has come to mean something more limited: the practice, invariably by female shamans called mudang or manshin, of spirit propitiation on behalf of people who hire them to perform ceremonies called kuts (Clark 2000, 45).

As Iida $(2013,140)$ may understand shamanism as not so much a religious tradition peculiar to a particular region, but rather as one of the universal religious phenomena that may occur throughout mankind in its entirety, Clark (2000, 45) points out that Korean shamanism was recognised in the 1980s and 1990s, during a time when young Koreans did new searching for their own "authentic" national identity, as emblems of true "Koreanness". In the diaspora, especially in Ikuno, a area in Ōsaka with a particularly dense Korean population, coming from Cheju-do island (South Korea), a perfoming of traditional rituals of Korean Shamanism served to build a network among them before the war (Iida 2013, 124).

After the war, however, such activities took the form of the chosen-dera 朝鮮 寺 (Japan-resident Korean temples) established in the Ikoma 生駒 mountain range (see Iida 1988). These number around 60 institutions, and while to the

14 Chesa is the key element of family life; it is the Confucian ancestral ritual, family ceremony that remembers one or two, or sometimes three, generations of ancestors in the father's lineage. Families honor their ancestor in chesa ceremonies on Lunar New Year's Day and on Chu'sok, the Harvest Festival. They also honor specific ancestors on the anniversary of their deaths, and the rest of the chesa ceremony is to remind everyone of the continuity of the family and of the debt that is still owed by younger generations to those who came before (Clark 2000,33, 98). 
outside world they appear to be nothing other than Buddhist temples, they have functioned as places for the rituals of Korean shamanism. In these rituals, for the purposes of propitiatory memorial services for the spirits of the dead (shisharei 死者霊), divine spirits (kamigami 神々) are summoned by a specialist shamanistic medium with spiritual abilities, and the spirits of the dead speak through the medium (kuchiyose 口寄せ). Korean shamanistic rituals, which take place over two or three days to a week, and sometimes up to ten days, are carried out in the temples of Mt. Ikoma. Korean shamanistic rituals of shorter duration were also carried out widely in a number of temples in Ōsaka City's Ikuno Ward, with its high concentration of Japan-resident Koreans, and the areas around it (Iida 2013, 125).

A basis in Korean traditional shamanism has been indicated as a reason for the development and spread of Korean Christianity, particularly the Full Gospel Church, in the later part of the twentieth century. Even in the case of the Full Gospel Church in Japan, most believers are "newcomer" females, and thus one would not move toward a flat denial of the theory of connections between aspects of these two religions (Christianity and Korean shamanism) relating to their basis in modern Korean society (ibid., 139).

\section{Folk Religion}

One of the important religious places of Koreans in Japan is Ikoma Mountain, which range straddles the border of the Kyōto, Ōsaka, and Nara districts. There are innumerable shrines and temples, churches connected with ascetic sects or the new religions, and other small shrines and sacred places which serve as foci to varieties of nature worship and animistic faiths. Almost all the various forms of Japanese folk religion are represented here. Many religious figures such as Shinto priests, Buddhist monks, ascetics, faith healers, diviners, mediums, peddlers of wonder drugs, and so forth gather in this area to serve the almost ten million people. Among these religious organizations connected to Ikoma is a unique group commonly known as the "Korean temples” (choosen-dera 朝鮮寺, such as Ishikirijinja 石切齐申社, Hozan-ji 宝山寺, Chogo Sonshi-ji 朝護孫子寺), supported by Korean residents of Japan, mostly from the Ōsaka area.

Hardacre's fieldwork-based study examined characteristics of Zainichi Korean temples in the Ikoma Mountain Range near Ōsaka and the function of the bosaru, female shamans, in the Zainichi Korean community. Hardacre showed that unlike their counterparts in Korea, many Japan-based bosaru established affiliations with 
Japanese Buddhist schools and played an important role in the identity formation of Zainichi Korean women. ${ }^{15}$

\section{Assimilation}

Assimilation into or of various Japanese religious traditions is another phenomenon. It may be that since there are common basic elements between Korean and Japanese religion, such as the merging of animism and Shamanism and a this-worldly orientation, it is easy for this religious assimilation to occur. Some Korean residents go to Japanese Buddhist temples to request funerals or memorial services, and it is not unusual for them to visit famous Japanese temples and shrines to pray for worldly benefits such as prosperity in business or relief from disease. There are also some who are involved in Shugendo organizations and actively participate in ascetic practices in the mountains or under waterfalls (Iida 1988, 158-60). In this case we can say that the role of religion within the migration process can be traced from the migratory act to changes in religious practice after migration to religion as an integrative force within the receiving society.

\section{Conclusions}

In making sense of a racial, ethnic, or national group — categories of modern peoplehood-one usually looks to language, religion, or custom and culture, but the identities are fluid and multifaceted; they can be at both the personal and group level and we negotiate them all the time. In the process of identity formation the Korean people in Japan face a variety of conflicts in the secular and religious world. Koreans in Japan are divided by politics, gender, class, occupation, education, age, and status. However young people have become interested in identity politics, not from the perspective of the north-south binary opposition, but with an eye to questioning their future in Japan. Many now actively debate ethnic identity, diaspora politics, and integration in or autonomy from Japanese society.

Because of the complex situation of Korean minority in Japan, the feeling of conflicts might also appear also in the realm of religious expression. For those who practice religion, their mutual identity as Koreans is reinforced and preserved through

15 The unique role of the bosaru has been pointed out. In Korea, for the most part men conduct Confucian-type ancestral rituals and women are associated with Buddhist or shamanistic practices. Women who were lay believers in their home country became religious practitioners through their experiences after coming to Japan (Hardacre in Akaike 2015). 
participation in ritual space, for example in the Christian Church or at Korean temples. Especially if we look at the group of "Korean temples" in the suburbs of Ōsaka, where the largest number of Koreans in Japan reside, we can say that it is a religious phenomenon consisting of a syncretism of Korean Shamanism, Korean Buddhism, and Japanese mountain religion (Iida 1988, 155). This shows us that the rituals performed by these believers clearly have undergone a transformation that is typically formed by the fact that it happened in Japan. The result is therefore different from what it would be in Korea. On the other hand one can view the place and role of the Korean temples from a different perspective, as part of the milieu of Ikoma as a living museum of folk religion. For example, Ikoma is a place of heightened religious awareness, where people transcend the boundaries of nationality.

Thus today's everyday life of Zainichi Koreans does not differ a lot from the Japanese; their culture is becoming more and more Japanese, as they wear same clothes, eat the same food, live in similar houses, and thus become more and more indifferent to the notion of Korean identity. However the most distinct element is the Confucian memorial ceremony chesa, ancestor worship, when the family gather to perform a ritual. This shows the great influence of Confucianism in their livesreverence for ancestors, respect for elders, and a consciousness of the mutual duties and obligations to relatives. Others may also feel deep affinity for the beauty and serenity of Buddhist temples and worship and may even visit Buddhist temples to pray. Korean Christians, having joined a religious tradition that is less tolerant of other faiths, might avoid Buddhism but they are much less likely even to be aware that they are guided throughout their lives by Confucian rules and understandings. But there are also Christians who have thought a lot about the mixture of Western religion and their own identity and conclude that their beliefs contain elements of shamanism, Confucianism, Buddhism, and Christianity all at the same time. Although Shinto adherents were unlikely to be Zainichi, the major world religions, ranging from Buddhism to Christianity, had faithfuls among both ethnic Korean and ethnic Japanese populations. Lie simplified this by saying $(2008,130)$ that first-generation Koreans engaged in ethnically distinct Buddhist temples and other ritual practices, but they were clearly on the wane by the 1980s. Prewar ethnic Koreans tended to practice strictly rituals of ancestor worship (chesa). Although almost universally practiced by the first generation, the Confucian ritual became vitiated and transformed under successive generations. Younger Zainichi either simplified or abandoned chesa and look up to their Japanese peers.

We can conclude that religious faith can work as a source of ethnic and even inter-ethnic solidarity among the Koreans in Japan in some cases (where not politically divided), but it some cases it cannot be a distinguishing factor from the ethnic Japan, as it leads to assimilation. 


\section{References}

Akaike, Noriaki. 2015. Book Review: Hardacre Helen. The Religion of Japan's Korean Minority; The Preservation of Ethnic Identity. Accessed October 15, 2015. https://nirc.nanzan-u.ac.jp/nfile/1399.

Brown, Lisa. 2015. "Caught Between Two Countries: Zainichi Koreans in Japan." Virginia Review of Asian Studies 17: 254-61.

Chapman, David. 2006. "Discourses of Multicultural coexistence (Tabunka kyōsei) and the 'Oldcomer' Korean Residenst of Japan.” Asian Ethnicity 7 (1): 89-102.

Clark, Donald N. 2000. Culture and Customs of Korea. Westport, Connecticut, London: Greenwood Press.

Gladney, Dru C., ed. 1998. "Introduction: Making and Marking Majorities." In Making Majorities Constituting the Nation in Japan, Korea, China, Malaysia, Fiji, Turkey, and The United States, 1-9. Stanford University Press Stanford, California.

Hardacre, Helen. 1990. Kuromizukyo and the New Religions of Japan. Princeton: Princeton University Press.

Hurh, Won Moo, and Kwang Chung Kim. 1990. "Religious Participation of Korean Immigrants in the United States."Journal for the Scientific Study of Religion 29 (1) (March): 19-34.

Hicks, George L. 1997. Japan's Hidden Apartheid: the Korean Minority and the Japanese. Aldershot: Ashgate.

Inadsugi, Tadashi. 2002. "Zainichi Kankoku, Chōsenjin no shakai idō.” In Minzoku kankei ni okeru ketsugō to bunri, edited by Tomio Tani, 559-95. Tōkyō: Minerva.

Iwabuchi, Koichi. 2005. "Political Correctness, Postcoloniality, and the Selfrepresentation of 'Koreanness' in Japan.” In Koreans in Japan. Critical Voices from the Margin, edited by Sonia Ryang, 55-73. London and New York: Routledge Curzon.

Iida, Takafumi. 1988. "Folk Religion among the Koreans in Japan - The Shamanism of the "Korean Temples." Japanese Journal of Religious Studies 15 (2-3): 155-82. Accessed October 25, 2015. https://nirc.nanzan-u.ac.jp/ nfile/2381.

Iida, Takafumi飯田剛史. 2002. Zainichi Korian no Shükyō to Matsuri. Minzoku to Shūkyō no Shakaigaku 在日コリアンの宗教と祭り一民族と宗教の社会 学-. Tōkyō: Sekai Shisōsha.

—. 2013. "The Full Gospel Church and Korean Shamanism in Japan-Resident Korean Society Shamanism as a Universal Foundational Religion.” Accessed May 6, 2015. http://nirc.nanzan-u.ac.jp/en/files/2013/04/PS-4-Iida.pdf. 
Kokot, Waltraud, Khachig Tölölyan and Carolin Alfonso, eds. 2004. "Introduction." Diaspora, Identity and Religion. New directions in theory and research, 1-8. London, New York: Routledge.

Kwang, Chung Kim, Stephen R. Warner, and Ho-Youn Kwon. 2001.

Korean American Religion in International Perspective. Pennsylvania: The Pennsylvania State University Press.

Lee, Grace. 2003. "The Political Philosophy of Juche." Stanford Journal of East Asian Affairs 3 (1): 105-12. Accessed October 9, 2015. https://web.stanford. edu/group/sjeaa/journal3/korea1.pdf.

Lie, John. 2008. Zainichi (Koreans in Japan). Diasporic Nationalism and Postcolonial Identity. Berkeley, Los Angeles, London: University of California Press.

Ministry of Justice (Hōmushō 法務省). 2015. “Zairyū gaikokujin tōkei (Kyūtōroku gakikokujin tōkei) tōkeihyō 在留外国人統計（旧登録外国人 統計）統計表.”June 5, 2015. Accessed November 15, 2015. http://www.estat.go.jp/SG1/estat/List.do?lid=000001139146.

"North Korean Christianity." Accessed November 25, 2015. http:// northkoreanchristians.com/juche-idea.html.

Ogawa, Nobuhiko 小川 伸彦, and Teraoka Shingo 寺岡 伸悟. 1993. "Mainoriti soshikino esunishiti - Zainichi Kwang San Kim Shi Shinzokukai Chōsa yori - マイノリティ組織のエスニシティ:--在日光山金氏親族会調査 より --.” The Japan Sociological Society 44 (2): 131-46, 240.

Pace, Enzo. 2005. “Religion and Migration.” In Comparative European Research in Migration, Diversity and Identities, edited by Wolfgang Boswich and Charles Husband, 113-23. Bilbao: Publications of University of Deusto.

Pakhomov, Oleg. 2011. "Re-entered Communities: Ethnic Discrimination Risk Management of the Korean Diaspora in Russia, the United States, and Japan.” PhD Dissertation. Kyoto: University of Kyoto.

Visočnik, Nataša. 2013. "Self and Other - Representations of the Korean Minority in Japan." Dve domovini 37: 113-21. 